\title{
Prevalence and Risk Factors of Occult Hepatitis C Virus infection in One Tertiary Egyptian Centre
}

\author{
Maha R Habeeb ${ }^{\mathrm{a}}$, Abd-Elmohsen Eldesoky ${ }^{\mathrm{a}}$, Mysaa E. Zaki ${ }^{\mathrm{b}}$, Mona Arfa ${ }^{\mathrm{c}}$, Dina Elhamady ${ }^{\mathrm{c}}$, \\ Mohamed Elegezy ${ }^{\mathrm{c}}$
}

\begin{abstract}
a Department of internal medicine (Hepatology and Gastroenterology), Mansoura University Faculty of Medicine, Egypt. ${ }^{b}$ Department of clinical pathology, Mansoura University Faculty of Medicine, Egypt. c Department of Tropical medicine, Mansoura University Faculty of Medicine, Egypt

Correspondence to: Maha R Habeeb, Department of internal medicine (Hepatology and Gastroenterology), Mansoura University Faculty of Medicine, Egypt.
\end{abstract}

Email:

maha_ragab68@yahoo.com

Received: 24 November 2020

Accepted: 8 February 2021

\section{Abstract}

Background: Occult hepatitis $\mathrm{C}$ infection (OCI)is a new form of hepatitis $\mathrm{C}$ virus (HCV) in which $\mathrm{HCV}$-RNA is present in hepatocytes or peripheral blood mononuclear cells(PBMCs)with undetectable plasma HCV-RNA, regardless of hepatic transaminase elevation. Aim: To find out prevalence of OCI infection in patients with anti $\mathrm{HCV}$ antibodies positive regardless to their transaminases and to study possible risk factors for OCI Patients and Methods: The current study included 100 patients in which HCV antibodies were detected by ELISA and HVC-RNA were examined in serum and PBMCs by real time polymerase chain reaction (PCR). Results: OCI was detected in $14 \%$ of enrolled patients. Having BMI $\geq 35.5 \mathrm{~kg} / \mathrm{m}^{2}$ demonstrating 5-times higher odds of exhibiting OCI in females while male sex had 10-times higher odds. Conclusions and Recommendations :Prevalence of OCI was $14 \%$ in anti $\mathrm{HCV}$ positive patients regardless hepatic transaminases level among them, obesity and male sex considered the main risk factors in this study, more studies on bigger number of patients are required.

Key words: Occult, Hepatitis C, Prevalence, Risk factors.

\section{Introduction:}

Hepatitis C virus (HCV) affects approximately 170 million people worldwide and accounts for an estimated 350,000 deaths annually. Detection of serum HCV-RNA and $\mathrm{HCV}$ antibodies are the basis of $\mathrm{HCV}$ diagnosis (1-4). However, a separate entity of this infection is occult HCV infection (OCI), characterized by detectable hepatocyte and peripheral blood mononuclear cell (PBMC) HCV-RNA in association with immeasurable 
serum HCV-RNA $(5,6)$. The two currently recognized types of OCI are seronegative OCI characterized by negativity of both anti$\mathrm{HCV}$ antibodies as well as serum HCV-RNA, and seropositive occult $\mathrm{HCV}$ infection, or secondary OCI, distinguished by positive anti-HCV antibodies but negative serum $\operatorname{HCV}$ - RNA $(7,8)$.

Occult HCV infection (OCI) has been detected in patients with cryptogenic liver disease at different rates e.g. about $10 \%$ as evidenced by some studies $(2,9)$ or about $74 \%$ as evidenced another (10). It also can be detected in the general population, as demonstrated in a study in which 9 out of 279 subjects $(3.3 \%)$ with normal enzymes and negative $\mathrm{HCV}$ antibodies and HCV- RNA in serum, were shown to be peripheral blood mononuclear cell (PBMC) HCV-RNA positive. A Chinese similarly demonstrated that $2.2 \%$ of blood donors were diagnosed as OCI (11).

In 2018, some researchers reported that $3.4 \%$ among blood donors have OCI (12).

Furthermore, OCI has been reported in special patient groups including autoimmune hepatitis (13), lymphoproliferative disease $(14,15)$, glomerular nephropathies (16), antiphospholipid syndrome (17), Type II mixed cryoglobulinemia (18-20), hemophilia (21), hepatitis B infection (22), alcoholic liver disease (23) and HIV infection (24).These findings need more studies to clarify prevalence and risk factors for OCI

While liver biopsy is the primary diagnostic tool for OCI by identification of hepatocyte HCV-RNA, the risks associated with this procedure, such as bleeding and accidental organ puncture, call for testing of PBMCs in most studies in order to establish the diagnosis of OCI. However, PBMC testing for HCV-RNA is inferior to hepatocyte testing with regards to true estimation of OCI prevalence, as PBMCs are positive in only about $70 \%$ of patients when compared to hepatocytes. Nevertheless, this rate of detection may increase with serial PBMC testing in cases of high OCI suspicion $(5,25$, 26), as evidenced in a recent study by Wang et al showing that detection rate of OCI was comparable between PBMC testing (92\%) and liver biopsy (27).

During the era when pegylated-interferon plus ribavirin was the standard therapy for patients with chronic hepatitis $\mathrm{C}$, Pardo et al conducted a study to evaluate the effect of this drug regimen on patients with OCI (28). Ten OCI patients with elevated ALT levels, positive PBMCs for HCV-RNA, and liver biopsy findings of necroinflammation were given treatment for 24 weeks then followed up for a further 24 weeks. By the end of the 
therapy period, $80 \%$ of patients demonstrated normalization of ALT levels and undetectable HCV-RNA in PBMCs. However, a sustained response could be achieved in only $30 \%$ of patients after 24 weeks of post-treatment follow-up. Quantification of PBMC HCV-RNA was not recorded at this time, although this would have been beneficial to further assess the effect of the administered therapy.

After the follow up period, five patients opted to undergo repeat biopsy, showing persistence of HCV-RNA. However, posttreatment biopsy in three cases demonstrated lower viral load, decreased number infected hepatocyte, and diminished necroinflammation and fibrosis. These results on OCI patients were in accordance with those typically observed in patients with chronic HCV infection at the time.

Recent introduction of the more efficient direct-acting treatment regimens for chronic hepatitis $\mathrm{C}$ revealed an increased association with persistent occult HCV infection following cessation of therapy for overt infection, with percentage of OCI following achievement of sustained virologic response (SVR) estimated to be $11.3 \%$ even reaching up to $55 \%$ in patients re-infected with $\mathrm{HCV}$ following liver transplantation $(8,29)$.
Therefore we aimed to determine the prevalence of OCI in Egyptian patients who have positive anti-HCV antibodies but negative serum HCV-RNA by PCR, and to study the possible risk factors.

\section{Patients and methods}

\section{Type of study is: Prevalence study}

It was conducted on patients recruited from the outpatient Hepatology clinics of Mansoura University Hospital in Egypt during the period from March 2016 to March 2018. Patients included in this study were those with positive antibodies for hepatitis $\mathrm{C}$ virus (anti-HCV antibodies) detected by third generation immunoassay method and negative hepatitis $\mathrm{C}$ virus RNA (HCV-RNA) by PCR in three consecutive plasma samples taken 6 months apart. Criteria for patients excluded from this study were those coinfected with hepatitis B virus, patients with positive HCV-RNA, and patients with other identifiable causes of liver affection, such autoimmune or alcohol hepatic diseases.

Design for this study was approved by the Mansoura Ethical Committee and written informed consent was obtained from each patient before being subjected to full medical history taking, complete clinical examination, and radiological evaluation by abdominal ultrasound. 


\section{Blood sampling and DNA testing}

Samples of $10 \mathrm{ml}$ blood were taken from each patient and divided into three aliquots, one without anticoagulant (for serum separation) and two aliquots with EDTA, one for plasma separation and the other for peripheral blood mononuclear cells (PBMCs) separation for determination of HCV-RNA.

Serum samples were used for determination of liver functions including aspartate aminotransferase (AST), alanine aminotransferase (ALT), total bilirubin and albumin by automated system Dialab 480. The measurement of alpha fetoprotein was done by enzyme linked immunoassay (ELISA).

\section{HCV-RNA Extraction from Plasma}

HCV RNA extraction was performed using Qiagen extraction kit for RNA (Qiagen, Courtaboeuf, France) according to the manufacturer's instructions.

\section{RNA Extraction from PBMCs}

Peripheral blood mononuclear cells (PBMCs) were prepared by density gradient method by use of Ficoll Hypaque density according to the manufacturer's instructions (Lymphoflot; Biotest, Derelict, Germany). The obtained mononuclear cells were washed with phosphate buffer solution and re- suspended after adjustment of the cell count to $1 \times 10$ ${ }^{6}$ cells/ml in PBS. Lysate of mononuclear cells was prepared by using Trizol reagent and shaking well to mix the cells, after which $100 \mu \mathrm{m}$ chloroform was added to each eppendorff, shaken adequately, and centrifuged at $13,200 \mathrm{rpm}$ for 15 minutes. The obtained supernatant was transferred to a sterile eppendorff to which $500 \mu$ m of $100 \%$ isopropanol was added then re-centrifuged at $13,200 \mathrm{rpm}$ for $15 \mathrm{~min}$.

The supernatant was then discarded and $500 \mu \mathrm{m}$ of $70 \%$ ethanol was added and centrifuged for 10min, after which the ethanol was poured out. After the eppendorff was left to dry for 10 mins, a $20 \mu \mathrm{m}$ of hydration solution were added then frozen at $-80^{\circ} \mathrm{C}$ until amplification.

\section{Hepatitis $C$ virus amplification by real-time PCR}

HCV-RNA was detected by using a kit supplied from Qiagen (HCV RT- PCR Kit lot No., Qiagen,courtaboeuf, France). Amplification was performed by use of Applied Biosystem. The quantitative realtime PCR kit of $\mathrm{HCV}$ is based on RNA reverse transcription process with consequent cDNA fragment amplification by PCR. The amplification process lies in repeated cycles 
of thermal DNA denaturing, primer annealing with complementary sequences, and completion of further polynucleotide chains by Taq-polymerase. An internal control (IC) sample corresponding to a stabilized RNA fragment was added to the sample being examined at the stage of nucleic acid isolation and intended for estimation of the efficacy of all the examination stages. The HCV quantitative real-time PCR kit and DNA probes, each of which contains a fluorescence label and fluorescence quencher, were included in the PCR mix. In case of specific cDNA product formation, a probe becomes destroyed leading to a fluorescence level growth registered by special appliances. DNA probes used for sought nucleic acid and IC PCR product detection are labeled with FAM and HEX fluorescence probes accordingly, allowing separate registration of $\mathrm{HCV} \mathrm{cDNA}$ and IC sample PCR results.

\section{Statistical analysis:}

Data were entered and analyzed using IBMSPSS software (2017, Version 25, Armonk, NY, IBM Corp.). Categorical data were expressed as $\mathrm{N}(\%)$ and compared using ChiSquare (or Fisher's exact) test. Quantitative data were initially tested for normality using Shapiro-Wilk test; data were considered normally distributed if $\mathrm{p}$ value >
0.050. Presence of outliers was tested for by inspecting the boxplots. Quantitative data were expressed as mean \pm SD (compared between two groups using Independent-

Samples t-test) if normally distributed with no significant outliers or as median $\left[25^{\text {th }}\right.$ percentile $-75^{\text {th }}$ percentile] (compared between two groups using Mann-Whitney $\mathrm{U}$ test) if not normally distributed and / or having significant outliers. The receiver operating characteristic (ROC) curve was plotted between the "sensitivity" (true positive rate) and "1- specificity" (false positive rate) across a series of cut-off points to find the optimal cut-off point that discriminates diseased and non-diseased subjects. Predicting the likelihood of a dichotomous variable was performed using logistic regression analysis.

\section{Results:}

Our main results are shown in fig . (1). HCV PBM level in Occult HCV was $8.1 \pm 1.4$ $\mathrm{IU} / \mathrm{ml}$, ranging from 5.5 to $10.5 \mathrm{IU} / \mathrm{ml}$. Table 1 shows that BMI (particularly BMI $\geq 35.5 \mathrm{~kg} / \mathrm{m}^{2}$ ) and moderate to morbid obesity were significantly higher in patients with occult HCV infection when compared to those without. Table 2 shows that higher BMI was a significant predictor of occult $\mathrm{HCV}$ infection (OCI), with patients having 
BMI $\geq 35.5 \mathrm{~kg} / \mathrm{m}^{2}$ demonstrating 5-times

higher odds of exhibiting OCI.

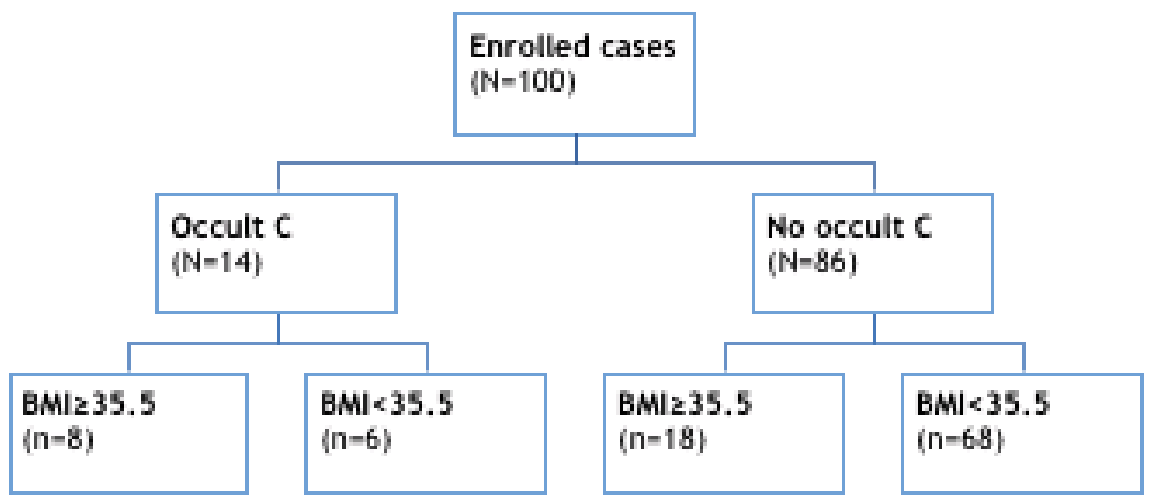

Fig. 1: Flow chart

Table (1): Comparison of clinical and laboratory data

\begin{tabular}{lllll}
\hline Variable & Group & & \multicolumn{2}{c}{ Test of significance } \\
& $\begin{array}{l}\text { No occult C } \\
\text { (N=86) }\end{array}$ & $\begin{array}{l}\text { Occult C } \\
(\mathbf{N = 1 4})\end{array}$ & $\begin{array}{l}\chi^{2} \text { or } \mathbf{Z} \\
\text { value }\end{array}$ & P value \\
\hline Age (years) & $55(45.8-6)$ & $50.5(46.3-60.3)$ & $\mathrm{Z}=-0.866$ & 0.386 \\
Se Male & $60(69.8 \%)$ & $8(57.1 \%)$ & $\chi^{2}=0.882$ & 0.384 \\
x Female & $26(30.2 \%)$ & $6(42.9 \%)$ & $\chi^{2}=0.997$ & 0.318 \\
Current smoking* & $20(23.3 \%)$ & $5(35.7 \%)$ & $\chi^{2}=0.005$ & 0.944 \\
Previous surgery* & $36(41.9 \%)$ & $6(42.9 \%)$ & $\chi^{2}=1.545$ & 0.214 \\
Presence of diabetes(DM)* & $13(15.1 \%)$ & $4(28.6 \%)$ & $\mathrm{Z}=-2.092$ & 0.036 \\
BMI(kg/m2) & $30.5(28-34.9)$ & $35.6(29.9-36)$ & $\chi^{2}=8.206$ & 0.004 \\
BMI $\geq 35.5$ & $18(20.9 \%)$ & $8(57.1 \%)$ & $\chi^{2}=6.262$ & 0.012 \\
Grade II or III obesity* & $21(24.4 \%)$ & $8(57.1 \%)$ & $\chi^{2}=0.152$ & 0.696 \\
Schistosomiasis* & $16(18.6 \%)$ & $2(14.3 \%)$ & $\mathrm{Z}=-0.219$ & 0.827 \\
HB (Hemoglobin) & $12.8(11.2-13.55)$ & $12.05(11.4313 .93)$ & $\mathrm{Z}=-1.11$ & 0.267 \\
TLC (Total leucocytic count) & $5.4(4.75-6.35)$ & $6.3(4.73-7)$ & $\mathrm{Z}=-0.517$ & 0.605 \\
PLT(Pletelet count) & $203(178-266)$ & $199(157.75245 .75)$ & $\mathrm{Z}=-0.050$ & 0.960 \\
ALB (Albumin) & $4.2(3.9-4.5)$ & $4.15(3.9-4.55)$ & $\mathrm{Z}=-0.795$ & 0.427 \\
BIL (Bilirubin) & $0.6(0.58-0.7)$ & $0.6(0.5-0.7)$ & $\mathrm{Z}=-1.46$ & 0.143 \\
AST(Aspartate transaminase) & $23(18.8-32.8)$ & $40(19.8-45)$ & $\mathrm{Z}=-1.59$ & 0.113 \\
ALT (Alanine transaminase) & $29(19.8-40.5)$ & $37(23-46.3)$ & $\mathrm{Z}=-1.27$ & 0.205 \\
RBG(Random blood glucose) & $106(95.8-121.3)$ & $113.5(97.5-188.3)$ & $\mathrm{Z}=-0.787$ & 0.431 \\
Creatinine & $0.8(7-9)$ & $0.9(0.7-1.1)$ & $\mathrm{Z}=-0.5$ & 0.960 \\
INR & $1.05(1.0-1.2)$ & $1.03(1-1.18)$ & $\mathrm{Z}=-1.197$ & 0.231 \\
FIB4 & $1.18(1.02-1.4)$ & $1.5(1.05-2.06)$ & &
\end{tabular}

Median (IQR) and compared by Mann-Whitney U test. 
Table (2): Univariate analysis for prediction of likelihood of OCI

\begin{tabular}{llcc}
\hline & Predictor & $\begin{array}{c}\text { Crude odds ratio [COR] } \\
(\mathbf{9 5 \%} \text { CI for COR })\end{array}$ & P value \\
\hline Age (years) & & $0.430(0.912-1.040)$ & 0.974 \\
Sex & Female & $\mathrm{R}$ & 0.352 \\
\multirow{2}{*}{ BMI cutoff value } & Male & $1.731(0.546-5.489)$ & $\mathrm{R}$ \\
\multirow{2}{*}{ Smoking } & $<35.5$ & $5.037(1.549-16.378)$ & $\mathbf{0 . 0 0 7}$ \\
Diabetic state & $\geq 35.5$ & $\mathrm{R}$ & 0.323 \\
& $\begin{array}{l}\text { Non-or ex-smoker } \\
\text { Current smoker } \\
\text { Non-diabetic } \\
\text { Diabetic }\end{array}$ & $1.833(0.551-6.101)$ & $\mathrm{R}$ \\
\end{tabular}

$\mathrm{P}$ value by simple binary logistic regression analysis

Table (3): Independent predictors of the likelihood of occult HCV infection

\begin{tabular}{|c|c|c|c|c|c|c|c|c|}
\hline \multirow{2}{*}{\multicolumn{2}{|c|}{ Predictor }} & \multirow{3}{*}{$\begin{array}{c}\text { B } \\
-0.067\end{array}$} & \multirow{3}{*}{$\frac{\text { SE }}{0.043}$} & \multirow{3}{*}{$\begin{array}{l}\text { Wald } \\
2.388\end{array}$} & \multirow{3}{*}{$\frac{\text { P value }}{}$} & \multirow{3}{*}{$\begin{array}{c}\text { OR } \\
0.936\end{array}$} & \multicolumn{2}{|c|}{ 95\% C.I for OR } \\
\hline & & & & & & & Lower & Upper \\
\hline Age(years) & & & & & & & 0.860 & 1.018 \\
\hline Sex & $\begin{array}{l}\text { Female } \\
\text { Male }\end{array}$ & 2.338 & 0.775 & 9.109 & 0.003 & $\begin{array}{c}\mathrm{R} \\
10.358\end{array}$ & 2.270 & 47.270 \\
\hline BMI cutoff value & $\begin{array}{l}<35.5 \\
\geq 35.5\end{array}$ & 1.668 & 0.847 & 3.882 & 0.049 & $\begin{array}{c}\mathrm{R} \\
5.301\end{array}$ & 1.009 & 27.856 \\
\hline Smoking & $\begin{array}{l}\text { Non- or ex-smoker } \\
\text { Current smoker }\end{array}$ & 0.213 & 0.791 & 0.073 & 0.787 & $\begin{array}{c}\mathrm{R} \\
1.238\end{array}$ & 0.263 & 5.831 \\
\hline Diabetic state & $\begin{array}{l}\text { Non-diabetic } \\
\text { Diabetic }\end{array}$ & 1.021 & 0.704 & 2.103 & 0.147 & $\begin{array}{c}\mathrm{R} \\
2.777\end{array}$ & 0.698 & 11.041 \\
\hline
\end{tabular}

$\mathrm{P}$ value by simple binary logistic regression analysis; $\mathrm{B}=$ binary logistic regression coefficient; $\mathrm{SE}=$ standard error;

$\mathrm{OR}=$ Odds ratio

Multivariate analysis was carried out to

predict the likelihood of occult HCV infection

being present. A binomial logistic regression

was performed to ascertain the effects of age

(in years), male sex, high BMI $\left(\geq 35.5 \mathrm{~kg} / \mathrm{m}^{2}\right)$, current smoking status and presence of DM on the likelihood that participants had OCI. Four studentized residuals with values of $2.006,2.559,2.466$ and 2.314 standard deviations were found but kept in the analysis. The logistic regression model was statistically $\quad$ significant, $\chi 2(5)=14.657, \quad \mathrm{p}$ $=0.012$. The model explained $24.6 \%$ (Nagelkerke $\mathrm{R}^{2}$ ) of the variance in occult $\mathrm{HCV}$ infection and correctly classified $86 \%$ of cases. Sensitivity was $71 \%$, specificity was $98.8 \%$, positive predictive value was $50 \%$ and negative predictive value was $86.7 \%$. This signifies a specific rather than a sensitive model.Of the 5 predictor variables, high BMI and male sex were statistically significant independent predictors, as seen in Table 3. Patients with $\mathrm{BMI} \geq 35.5 \mathrm{~kg} / \mathrm{m}^{2}$ had 5 times 
higher odds of exhibiting OCI whereas male sex had10 times higher odds.

\section{Discussion:}

Hepatitis C infection is a global health problem, the prevalence of it varies throughout the world, with the highest prevalence in Egypt (30).

Anew class of HVC infections, occult HCV, is defined as two different types either cryptogenic type in which patients have no anti HCV antibodies, or secondary type in which patients have anti $\mathrm{HCV}$ antibodies and had cleared HCV infection either spontaneously or after therapy, in both types detection of HCV-RNA in hepatocytes is the gold standard and most accurate alternatively detect HCV- RNA in PBMCs which is less invasive and easy to do.

Different studies have reported the prevalence of OCI in different populations; up till now, its associated risk factors have not been established yet (12).

Of the 100 patients included in the current study who spontaneously cleared $\mathrm{HCV}$ proved by positive test for anti-HCV antibodies and negative for serum $\mathrm{HCV}$ RNA, 14 patients (14\%) exhibited genomic HCV-RNA detectable in PBMCs. While findings from this study are consistent with different prevalence rates, with those reported by numerous other studies $(27,31,32,33,34$, 35 , 36), they contradict some accounts reporting no occult $\mathrm{HCV}$ infection $(37,38)$. This may possibly be due to use of less accurate and less sensitive commercial assays in these studies. However, all these documented studies on OCI comprised a small number of patients, typically ranging from 5 patients to a maximum of 27 .

A study done recently (27) evaluated the prevalence of OCI in hepatocytes and PBMCs of three groups of patients, either naturally resolved $\mathrm{HCV}$ infection or achieved SVR at 24 weeks (SVR24) following therapy with DAAs or pegylated \ribavirin (PR), finding HCV-RNA (by RNA scope assay of liver biopsies and PMBCs) in about $11 \%$ of all patients groups, $15 \%$ in DAA group, $10 \%$ in PR group and $6.7 \%$ in spontaneously resolved group. This finding suggest that complete 'cure' is an unlikely occurrence as evidenced by the higher prevalence of $\mathrm{HCV}$ in patients treated with DAA and the relapse at 48 weeks post-treatment of one patient treated by PR. Peripheral blood mononuclear cells (PBMCs) were positive for HCV-RNA in almost all patients with detectable HCV-RNA in hepatocytes $(12 / 13 ; 92.3 \%)$.

This finding is of particular interest in that it suggests that monitoring of PMBCs may be used for detection of occult $\mathrm{HCV}$ infection in 
post-treatment longitudinal follow-up, reserving liver biopsy for cases demonstrating negative PBMC HCV-RNA. However, previous studies had demonstrated a lower detection rate of HCV RNA at about $70 \%$ by PBMC monitoring $(5,26)$.

Researchers found that the prevalence of OCI in blood donors population (seronegative to $\mathrm{HCV}$ antibodies) was $3.4 \%$ by testing $\mathrm{HCV}$ RNA in both hepatocyte and PMBCs (12). On the other hand some other researchers test for $\mathrm{HCV}$ RNA in PMBCs in patients who are spontaneously or therapeutically clear the virus, and found complete clearance of $\mathrm{HCV}$ from PMBCs (39).

The current study examined PBMC only for genomic RNA, avoiding liver biopsy in an attempt to avert risk of complications. Studies with much larger sample size are needed to adequately determine whether PBMC viral load correlates with that of hepatocytes.

In the recent study (27), it was proved that prolonged hepatic inflammation and higher fibrosis score were more likely seen in patients with occult $\mathrm{HCV}$ infection whereas regression of fibrosis was characteristic of patients without OCI.
Continuous viral replication in hepatocytes following clearance of $\mathrm{HCV}$ leads to ongoing hepatic inflammation with deterioration of clinical condition. These histopathological findings seen in occult $\mathrm{HCV}$ infection are particularly concerning in cases of unchecked post -treatment patients because OCI does not necessarily manifest with abnormalities of transaminases and is unrelated to baseline viral loads. Therefore, it is essential to determine diagnostic and predictive biomarkers for occult $\mathrm{HCV}$ infection to be used particularly in absence of liver biopsy (27).

To predict the likelihood of presence of occult $\mathrm{HCV}$ infection being present, several independent predictor variables including age in years, male sex, high BMI $\geq 35.5 \mathrm{~kg} / \mathrm{m}^{2}$, current smoking status and presence of DM were evaluated in this study. Of these, high BMI and male sex were found to be statistically significant, with patients having BMI $\geq 35.5 \mathrm{~kg} / \mathrm{m}^{2}$ demonstrating 5- times higher odds of exhibiting OCI that come in concordance with results reported by researchers who found that overweight is a significant clinical risk factor (40). While male sex had 10 times higher odds this is compatible with the study which found that double numbers of males than females affected as OCI (12). 


\section{Conclusion and recommendations:}

We concluded that prevalence of OCI was $14 \%$ after spontaneous clearance of the virus. BMI at cut off value $\geq 35.5 \mathrm{~kg} / \mathrm{m}^{2}$ and male sex can be risk factors for OCI.

Further studies with larger patient groups are necessary to fully determine the risk factors of occult HCV infection thus enabling treatment options without entailing liver biopsy. To date, it remains unknown what duration is required for adequate monitoring of OCI patients and whether further treatment would benefit these patients.

\section{References:}

1. Lauer GM and Walker BD. Hepatitis $\mathrm{C}$ virus infection. N Engl J Med. 2001;345(1):41-52.

2. Bokharaei-Salim F, Keyvani H, Monavari SH, Alavian SM, Madjd Z, Toosi MN, et al. Occult hepatitis $\mathrm{C}$ virus infection in Iranian patients with cryptogenic liver disease. J Med Virol. 2011;83(6):989-95.

3. Zaltron S, Spinetti A, Biasi L, Baiguera C, Castelli F. Chronic HCV infection: epidemiological and clinical relevance. BMC Infect Dis. 2012;12 Suppl 2:S2

4. Jamali R. Epidemiologic Studies on Viral Hepatitis: A Short Review. Thrita. 2014;3(1):e15376.

5. Castillo I1, Pardo M, Bartolomé J, Ortiz-Movilla N, Rodríguez-Iñigo E, de Lucas S,et al.. Occult hepatitis $\mathrm{C}$ virus infection in patients in whom the etiology of persistently abnormal results of liverfunction tests is unknown. J Infect Dis. 2004 Jan $1 ; 189(1): 7-14$.
6. Ocana S, Casas ML, Buhigas I, Lledo JL. Diagnostic strategy for occult hepatitis B virus infection. World J Gastroenterol 2011;17:15531557.

7. Alyssa Austria and George Y. Wu. Occult Hepatitis C Virus Infection: A Review.Journal of Clinical and Translational Hepatology 2018 vol. 6 | $155-160$.

8. Elmasry S, Wadhwa S, Bang BR, Cook L, Chopra S, Kanel G,et al. Detection of Occult Hepatitis C Virus Infection in Patients Who Achieved a Sustained Virologic Response to DirectActing Antiviral Agents for Recurrent Infection. After Liver Transplantation. Gastroenterology. 2017 Feb;152(3):550-553.

9. Keyvani H, Bokharaei-SalimF, Monavari SH, Esghaei M, NassiriToosi M, FakhimS, et al. Occult hepatitis $\mathrm{C}$ virus infection in candidates for liver transplant withcryptogenic cirrhosis. Hepat Mon 2013;13:e11290.

10. Rezaee-Zavareh MS, Hdi R, Karimi-Sari H, Hossein Khosravi M, Ajudani R, Dolatimehr F, et al. (2015) Occult HCV Infection: The Current State of Knowledge. Iran Red Crescent Med J 17: e34181.

11. Lin H, Chen X, Zhu S, Mao P, Zhu S, Liu Y, et al. Prevalence of occult hepatitis Cvirus infection among blood donors in Jiangsu, China. Intervirology 2016;59:204-210.

12. Martinez-Rodriguez M, Uribe-Noguez L, ArryoAnduiza C, Mata-Marin J, Portillo-Lopez M, Ocana- Mondragon A. Prevelence and risk factors of Occult Hepatitis $\mathrm{C}$ infection in blood donors from Mexico City.Pols One Oct. 2018; Vol.13(10): page 1-11.

13. RezaeeZavareh MS, Alavian SM, Karimisari H, Shafiei M, SaiediHosseini SY. Occult hepatitis C virus infection in patients with autoimmune hepatitis. Hepat Mon. 2014;14(8):e16089. 
14. Youssef SS, Nasr AS, El Zanaty T, El Rawi RS, Mattar MM. Prevalence of occult hepatitis C virus in egyptian patients with chronic lymphoproliferative disorders. Hepat Res Treat. 2012;2012:429784.

15. Farahani M, Bokharaei-Salim F, Ghane M, Basi A, Meysami P, Keyvani H. Prevalence of occult hepatitis $\mathrm{C}$ virus infection in Iranian patients with lymphoproliferative disorders. J Med Virol. 2013;85(2):235-40.

16. Castillo I, Martinez-Ara J, Olea T, Bartolome J, Madero R, Hernandez E, et al. High prevalence of occult hepatitis $\mathrm{C}$ virus infection in patients with primary and secondary glomerular nephropathies. Kidney Int. 2014;86(3):619-24.

17. Prieto J, Yuste JR, Beloqui O, Civeira MP, Riezu JI, Aguirre B, et al. Anticardiolipin antibodies in chronic hepatitis $\mathrm{C}$ : implication of hepatitis $\mathrm{C}$ virus as the cause of the antiphospholipid syndrome. Hepatology. 1996;23(2):199-204. doi: 10.1002/hep.510230201. [PubMed: 8591841]

18. Karlsberg PL, Lee WM, Casey DL, Cockerell CJ, Cruz PJ. Cutaneous vasculitis and rheumatoid factor positivity as presenting signs of hepatitis $\mathrm{C}$ virus-induced mixed cryoglobulinemia. Arch Dermatol. 1995;131(10):1119-23.

19. Walker NJ, Zurier RB. Liver abnormalities in rheumatic diseases. Clin Liver Dis. 2002;6(4):933-46.

20. Casato M, Lilli D, Donato G, Granata M, Conti V, Del Giudice G, et al. Occult hepatitis C virus infection in type II mixed cryoglobulinaemia. J Viral Hepat. 2003;10(6):455-9.

21. Parodi C, Culasso A, Aloisi N, Garcia G, Baston M, Corti M, et al. Evidence of occult HCV genotypes in haemophilic individuals with unapparent HCV mixed infections. Haemophilia. 2008;14(4):816- 22.

22. Castillo I, Bartolome J, Quiroga JA, Carreno V. High prevalence of occult hepatitis $\mathrm{C}$ virus infection in patients with chronic hepatitis B virus infection. J Med Microbiol. 2013;62(Pt 8):12358.
23. Saad, Y S.,Zakaria, I. Ramzy, M E Z Raziky,O. Shaker,W. et al., "Prevalence of occult hepatits C in Egyptian patients with non alcoholic fatty liver disease," Open Journal of Internal Medicine, vil. 1 , pp. 33-37, 2011.

24. Gatserelia L, Sharvadze L, Karchava M, Dolmazashvili E, Tsertsvadze T.Occurrence of occult HCV infection among Hiv infected patients in Georgia. Georgian Med News 2014;(226):37-41.

25. Castillo I, Bartolomé J, Quiroga JA, Barril G, Carreño V. Long-term virological follow up of patients with occult hepatitisC virus infection. Liver Int 2011;31: 1519-1524.

26. Barril G, Castillo I, Arenas MD, Espinosa M, Garcia-Valdecasas J, GarciaFernandez N, et al. Occult hepatitis $\mathrm{C}$ virus infection among hemodialysis patients. J Am Soc Nephrol 2008; 19:2288-2292.

27. Wang $\mathrm{Y}$, Rao H, and Zhao J . Detection of residual HCV-RNA in patients who have achieved sustained virological response is associated with persistent histological abnormality. EBioMedicine 2019.Aug;46:227235.

28. Pardo M, López-Alcorocho JM, Castillo I, Rodríguez-Iñigo E, Perez-MotaA,Carreño V. Effect of anti- viral therapy for occult hepatitis C virus infection. Aliment Pharmacol Ther. 2006;23:1153-1159.

29. Yousif MM, ElsadekFakhr A, Morad EA, Kelani H, Hamed EF, Elsadek HM,et al. Prevalence of occult hepatitis $\mathrm{C}$ virus infection in patients who achieved sustained virologic response to directacting antiviral agents. Infez Med. 2018 Sep $1 ; 26(3): 237-243$.

30. Frank,C. Mohamed, M. K. Strickland G. T. and Lavanchy. D. "The role of parenteral antischistosomal therapy in the spread of hepatitis C virus in Egypt," Lancet, vol. 355, no. 9207, pp. 887-891, 2000. 
31. Carreño V, Castillo I, Bartolomé J, RodríguezIñigo E, Ortiz-Movilla $\mathrm{N}$, de Lucas S,et al. Comparison of hepatitis $\mathrm{C}$ virus RNA detection in plasma, whole blood and peripheral blood mononuclear cells of patients with occult hepatitis C virus infection. J Clin Virol 2004; 31:312-313.

32. Pham TN, MacParland SA, Mulrooney PM, Cooksley H, Naoumov NV, Michalak TI. Hepatitis $\mathrm{C}$ virus persistence after spontaneous or treatment-induced resolution of hepatitis C. J Virol 2004; 78:5867-5874.

33. Falcón V, Acosta-Rivero N, Shibayama M, LunaMunoz J, Miranda-Sanchez M, de la Rosa MC, et al. Evidences of hepatitis $\mathrm{C}$ virus replication in hepatocytes and peripheral blood mononuclear cells from patients negative for viral RNA in serum. Am J Infect Dis 2005;1:34-

34. Radkowski M, Horban A, Gallegos-Orozco JF, Pawelczyk A, Jablonska J, Wilkinson J, et al. Evidence for viral persistence in patients who test positive for antihepatitis $\mathrm{C}$ virus antibodies and have normal alanine aminotransferase levels. J Infect Dis 2005; 191:1730-1733.

35. Veerapu NS, Raghuraman S, Liang TJ, Heller T, Rehermann B. Sporadic reappearance of minute amounts of hepatitis $\mathrm{C}$ virus RNA after successful therapy stimulates cellular immune responses. Gastroenterology 2011;140:676685.e1.
36. Hani A Aboalam, Hebat-Allah G Rashed, Mohamed A Mekky, Hanan M Nafeh, Osman A Osman. Prevalence of occult hepatitis $\mathrm{C}$ virus in patients with HCVantibody positivity and serum HCV RNA negativity J Curr Med Res Pract 2016; 1:12-16.

37. De Mitri MS, Morsica G, Chen CH, Mele L, Baccarini P, Chianese $\mathrm{R}$, et al.Complete eradication of hepatitis $\mathrm{C}$ virus after interferon treatment for chronic hepatitis C. Ital J Gastroenterol Hepatol 1997; 29:255-261.

38. Teramura K, Fukuda A, Kobayashi H, Yoshimoto S, Kawashima H, Ohsawa N. Virus elimination and histologic improvement in patients with chronic hepatitis $\mathrm{C}$ treated with interferon alpha. J Clin Gastroenterol 1997; 25:346-351.

39. Bernardin F, Tobler L, Walsh I, Williams JD, Busch M, Delwart E. Clearance of hepatitis C virus RNA from the peripheral blood mononuclear cells of blood donors who spontaneously or therapeutically control their plasma viremia. Hepatology. 2008;47(5): 14461452.

40. El-moselhy E, Abd El-Aziz A, Atlam S, Mnsour R,Amin H, Kabil T, Elkhateeb A.Prevelence and Risk Factor of Overt-and Occult Hepatitis C Virus Infection among Chronic Kidney Disease Patients Under Regular Hemodialysis in Egypt.The Egyptian Journal of Hospital Medicine Oct.2015; Vol.61:653-669.

To cite this article: Maha R Habeeb, Abd-Elmohsen Eldesoky, Mysaa E. Zaki, Mona Arfa , Dina Elhamady, Mohamed Elegezy. Prevalence and Risk Factors of Occult Hepatitis C Virus infection in one Tertiary Egyptian centre. BMFJ 2021;38(1):395-406. DOI: 10.21608/bmfj.2021.49434.1347 